\title{
Evaluation of Mandibular Implant Sites: Correlation between Panoramic and Linear Tomography
}

\author{
Maria Ivete Bolzan ROCKENBACH² \\ Maria Carméli Correia SAMPAIO ${ }^{1}$ \\ Lino João da $\operatorname{COSTA}^{1}$ \\ Nilza Pereira da $\operatorname{COSTA}^{2}$ \\ ${ }^{1}$ Department of Dental Clinics and Community Dentistry, Federal University of Paraiba, João Pessoa, PB, Brazil \\ ${ }^{2}$ Department of Surgery, Faculty of Dentistry, PUCRS, Porto Alegre, RS, Brazil
}

\begin{abstract}
The reliability of the linear tomography and panoramic radiography made with X-ray equipment was evaluated (Vera View Scope X600 ; Morita). The sample was composed of 20 dry human hemimandibles, in which the area selected for analysis was $1.5 \mathrm{~cm}$ distal from the limit set before the mental foramen. Four measurements were made. The images obtained were drawn on acetate paper and the hemimandibles cut at the demarcated area. The measurements were made using a digital electronic pachymeter. The values found for the radiographic images were compared to those obtained in the mandibular specimens and submitted to statistical evaluation by the Wilcoxon test. It was concluded that both techniques were reliable for the accomplishment of vertical linear measurements in the selected area. However, a $2.0 \mathrm{~mm}$ safety margin is recommended.
\end{abstract}

Key Words: mandible, linear tomography, panoramic radiography, implants.

\section{INTRODUCTION}

The main objectives of preoperative assessment in dental implantology are to determine if there is sufficient bone in the alveolar ridge and to determine the precise position of the anatomical structures in order not to be damaged during surgery $(1,2)$.

For the dental implant insertion in the posterior portion to the mental foramen, the localization of the mandibular canal has to be precisely determined. Therefore, several studies have been performed to determine the best method for the localization of the mandibular canal and its preservation during surgical procedures (3-6). Among the most studied techniques are panoramic radiography and conventional tomography.

Panoramic radiography is a widely used technique because it has the advantage of providing, in a single film, the image of both jaws, with a relatively low radiation dose, in a short period of time, and at lower cost if compared to more sophisticated techniques. In implantology, this technique can offer information about the localization of anatomic structures and vertical bony dimensions. However, without knowing the magnification degree and the image distortion, mistakes in measurements may occur. In addition, panoramic radiography does not provide the buccolingual view of the bone.

Tomography allows transversal image obtainment of the alveolar bone. Linear tomography has been reported to be one of the best radiographic methods for the preoperative evaluation of proposed sites for dental implants (6-8). This technique has several advantages in relation to computerized tomography, such as cost, radiation dose, speed, ease of execution and the nonformation of artifacts in the presence of metallic objects. However, its exactness and validity have been questioned because factors such as non-uniform magnification, limitations of the movement of the x-ray tube and a deficient blurring pattern can decrease image sharpness and precision of measurements (9-12).

When image systems for treatment with osseointegrated implant planning are compared, each method

Correspondence: Dra. Maria Ivete Bolzan Rockenbach, Rua Demétrio Ribeiro 126, Apto 404, Centro, 90010-312 Porto Alegre, RS, Brasil. Tel: +55-51-3212-0655. e-mail: iveterockenbach@ig.com.br 
has benefits and limitations. The professional has to determine what information has to be obtained, so that he can choose the system according to cost/benefit relations.

Thus, the objective of this study was to evaluate the reliability of linear measurements in the posterior region of the mandible comparing the obtained values in dry specimens with the corresponding images in linear tomographies and in panoramic radiographies.

\section{MATERIAL AND METHODS}

Twenty dry edentulous hemimandibles were selected at $1.5 \mathrm{~cm}$ distal from the anterior limit of the

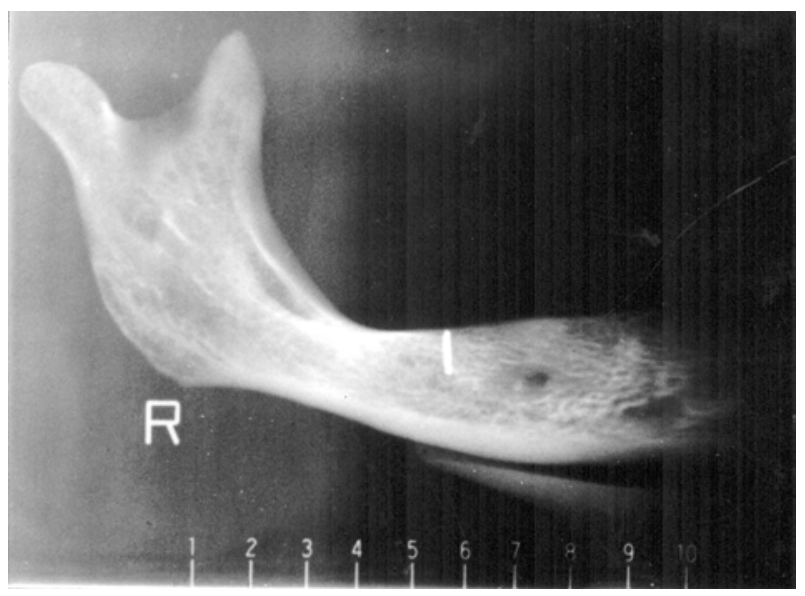

Figure 1. Panoramic radiography with scales.

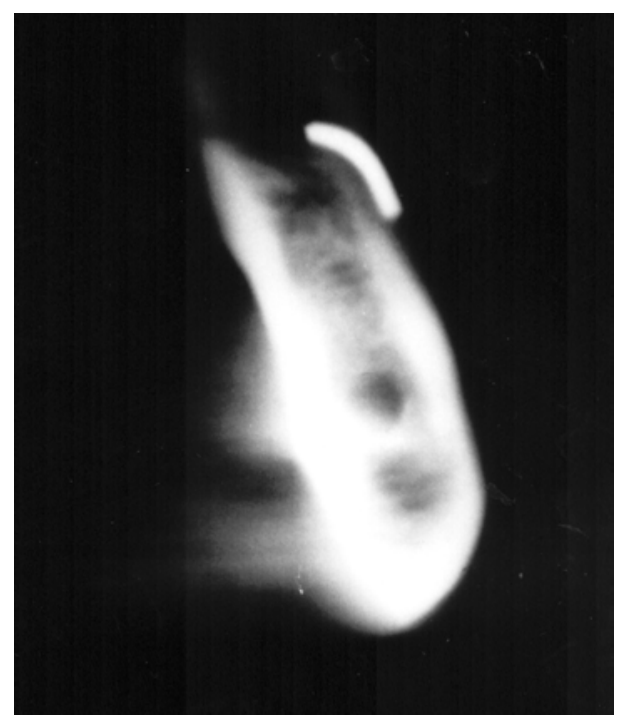

Figure 2. Image of one of the selected tomographic slices. mental foramen. A metallic wire was fixed at the buccal portion of the alveolar ridge, serving as reference in the radiographic exams for the localization of the proposed research area.

The examinations were made utilizing the Vera View Scope X-600 equipment (Morita Co.; Tokyo, Japan), in which each mandible specimen was positioned with its base parallel to the ground and with the median line coinciding with the luminous indicator of the equipment. Mandibles were fixed firmly to the chin support utilizing a block of wax to avoid any movement during radiography.

Initially, a panoramic radiograph was taken and, through the scale present in this radiograph, the area for the linear tomography was identified. In cases in which the metallic wire was located in an intermediate position, as seen in Figure 1, a more mesial area was chosen. Three tomographic slices ( $5.0 \mathrm{~mm}$ thick) were obtained in each selected region, according to the equipment scheme (Figure 2).

The film utilized for both techniques was XOmat RP XRP-1 (Kodak, Rochester, NY), and the determined electric factors of exposure were the smallest ones established for this equipment. Two lead plates were placed in front of the equipment diaphragm, in order to impede film superexposure, overcoming the lack of soft tissues and the absence of the opposite side of the mandible. Radiographic processing was automatic and the AT 2020 equipment (Air Techniques Co., Hicksville, NY) was utilized.
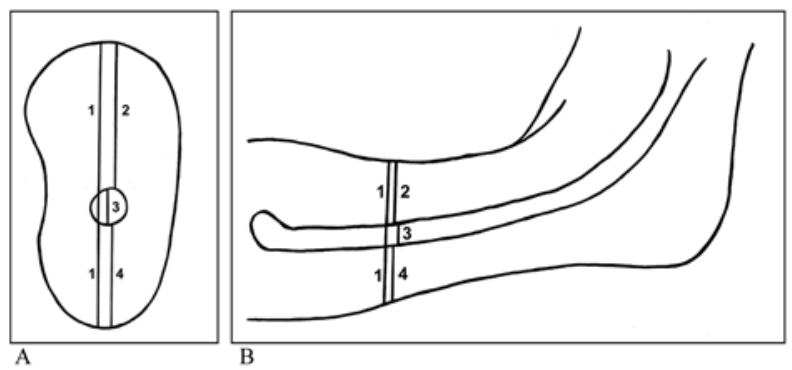

Figure 3. Schematic illustration of the measurements made of the linear tomograph (left) and the panoramic radiograph (right): $1=$ Distance between the upper limit of the alveolar ridge and the lower limit at the mandible base.

$2=$ Distance between the upper limit of the alveolar ridge and the upper limit of the mandibular canal.

$3=$ Diameter of the mandibular canal.

$4=$ Distance between the lower limit of the mandibular canal and the lower limit of the mandible base. 
After obtaining the radiographic images, with the utilization of a viewing box, acetate paper (Ultraphan, St. Paul, MN) and $0.5 \mathrm{~mm}$ graphite, the anatomic structures of interest were delineated on the panoramic images, as well as on the tomographic slices. From the three tomographic images obtained in each region, the one that presented the best definition of osseous structure and of metallic wire utilized as a marker was selected. The marked structures, in the panoramic radiographs, as well as in the linear tomographs, were the upper limit of the alveolar ridge, the upper and lower limits of the mandibular canal and the lower limit of the mandible base.

Utilizing a digital electronic pachymeter (727 Series/Starret), 4 measuresments were made on the copies as explained in Figure 3. The measurements were corrected according to a magnification degree of 1.3 in the panoramic radiographs and of 1.7 in the linear tomographs.

Mandibles were then sectioned according to the marked regions, in a $90^{\circ}$ angle in relation to their base, and the measurements were made directly on the specimens, utilizing the same reference points established for the radiographs and the same electronic digital pachymeter.

Table 1. Results of the Wilcoxon signed-ranks test for the four measurements.

$\begin{array}{ll}\text { Measurement } 1 & \\ \text { Mandibular Specimen X Linear Tomography } & \mathrm{p}=0.0001 \\ \text { Linear Tomography X Panoramic Radiography } & \mathrm{p}=0.0001 \\ \text { Mandibular Specimen X Panoramic Radiography } & \mathrm{NS} \\ & \\ \text { Measurement 2 } & \\ \text { Mandibular Specimen X Linear Tomography } & \mathrm{p}=0.0001 \\ \text { Mandibular Specimen X Panoramic Radiography } & \mathrm{p}=0.007 \\ \text { Linear Tomography X Panoramic Radiography } & \mathrm{NS} \\ & \\ \text { Measurement 3 } & \\ \text { Mandibular Specimen X Linear Tomography } & \mathrm{NS} \\ \text { Linear Tomography X Panoramic Radiography } & \mathrm{NS} \\ \text { Mandibular Specimen X Panoramic Radiography } & \mathrm{NS} \\ & \\ \text { Measurement 4 } & \\ \text { Mandibular Specimen X Linear Tomography } & \mathrm{p}=0.028 \\ \text { Linear Tomography X Panoramic Radiography } & \mathrm{p}=0.038 \\ \text { Mandibular Specimen X Panoramic Radiography } & \mathrm{NS}\end{array}$

NS = no statistically significant differences.

See figure 3 for details of measurements.
The results of the four measurements obtained in panoramic radiographs and linear tomographs were compared with the real measurements obtained directly from the mandibular specimens using the non-parametric Wilcoxon signed-ranks test. The analysis was made separately for each of the four measurements.

\section{RESULTS AND DISCUSSION}

Statistically significant differences were found for measurements 1, 2 and 4, when the linear tomographic images were compared with the anatomic specimens (Table 1). These results are similar to those reported by other authors $(9,10,12-14)$. The statistical differences can be related to the deficient blurring pattern which occurs in linear tomographs that produces a reduction of the image resolution, making the visualization of the structures difficult (9-12). Another factor that may explain these differences is the projection of the X-ray beam, which must be parallel to the alveolar ridge axis in order to produce a perpendicular radiographic slice. An oblique slice makes the anatomic details look blurred showing an augmented jaw $(13,15,16)$.

The linear tomography showed a tendency to overestimate the measurements obtained for the mandibular specimens. However, the tomographic measurements were above $2.0 \mathrm{~mm}$ in only $1.66 \%$ of the samples and above $1.5 \mathrm{~mm}$ in $18.33 \%$ of the samples, which is similar to results reported by Bahlis (17).

In measurement 2 (distance between the upper limit of the alveolar ridge and the upper limit of the mandibular canal), there was a tendency of the panoramic radiography to overestimate the values of the mandibular specimen. Nevertheless, these measurements were above $1.0 \mathrm{~mm}$ in $8.33 \%$ of the sample and above $1.5 \mathrm{~mm}$ in only $1.66 \%$ of the studied sample.

Catic et al. (18) pointed out that linear measurements made in panoramic radiographs on one side of the mandible are near the true dimensions of the dry mandible. However, correct positioning of the patient is indispensable so that these measurements can be reliable $(19,20)$.

In relation to the mandibular canal (measurement 3 ), no statistically significant differences were observed between the two methods studied, a 
fact that is in agreement with the findings of Lindh and Petersson (4), when they examined the region located at $2.0 \mathrm{~cm}$ posterior to the mental foramen.

Linear tomography limitations indicate the need for additional studies and for an improvement of this technique. In order to obtain better results, researchers have utilized guides with radiopaque markers that facilitate the slice layer localization $(8,10)$. The metallic references can also provide information related to the image quality, as verified in this study. Besides this, alignment systems with the optic fiber have to be used. Several brands of these systems are available and they facilitate the positioning of the patient, as well as the localization of the proposed sites $(7,8,10,12)$.

Although several image diagnostic methods are available to evaluate proposed sites for implants, currently none of them is considered ideal for pre- and postoperative analyses. Therefore, Frederiksen (2) and Silverstein et al. (8) suggest a combination of various techniques to obtain reliable information.

We conclude that the linear tomography overestimated the measurements obtained in the mandibular specimens, whereas the panoramic radiography presented values close to the true measurements of the dry mandibles. Both techniques were reliable for the accomplishment of vertical linear measurements in the selected area; however, we recomend the use of a 2.0 $\mathrm{mm}$ safety margin in the evaluation of implant sites.

\section{ACKNOWLEDGMENTS}

The authors would like to thank Dra. Elaine Bauer Veeck for her contributions during the development of this study. Dra. M.I.B. Rockenbach's studies were supported by a CAPES master's fellowship.

\section{RESUMO}

Objetivando a análise de sítios para colocação de implantes, avaliou-se a confiabilidade da tomografia linear e da radiografia panorâmica realizadas com o equipamento de raios-X Vera View Scope X-600 (Morita). A amostra constituiu-se de 20 hemimandíbulas humanas secas, cuja área selecionada localizou-se a 1,5 $\mathrm{cm}$ para distal do limite anterior do forame mental. Quatro medidas foram estabelecidas. As imagens obtidas foram traçadas em papel acetato e as hemimandíbulas seccionadas na região demarcada. As mensurações foram realizadas com a utilização de um paquímetro eletrônico digital (Starret). Os valores encontrados nas imagens radiográficas foram comparados com aqueles obtidos nos espécimes mandibulares e submetidos a avaliação estatística pelo teste de Wilcoxon. Concluiu-se que ambas as técnicas são confiáveis para a realização de medidas lineares verticais na área selecionada, no entanto, recomenda-se a utilização de uma margem de segurança de $2,0 \mathrm{~mm}$.

\section{REFERENCES}

1. Abrahams JJ. The role of diagnostic imaging in dental implantology. Radiol Clin North Am 1993;31:163-180.

2. Frederiksen NL. Diagnostic imaging in dental implantology. Oral Surg Oral Med Oral Pathol Oral Radiol Endod 1995;80:540-554.

3. Dharmar S. Locating the mandibular canal in panoramic radiographs. Int J Oral Maxillofac Implants 1997;12:113-117.

4. Lindh C, Petersson A. Radiologic examination for location of the mandibular canal: a comparison between panoramic radiography and conventional tomography. Int $\mathrm{J}$ Oral Maxillofac Implants 1989;4:249-253.

5. Lindh C, Petersson A, Klinge B. Visualisation of the mandibular canal by different radiographic techniques. Clin Oral Impl Res 1992;3:90-97.

6. Stella JP, Tharanon W. A precise radiographic method to determine the location of the inferior alveolar canal in the posterior edentulous mandible: implications for dental implants. Part 2: clinical application. Int J Oral Maxillofac Implants 1990;5:23-29.

7. Lee S, Morgano SM. A diagnostic stent for endosseous implants to improve conventional tomographic radiographs. J Prosthet Dent 1994;71:482-485.

8. Silverstein LH, Melkonian RW, Kurtzman D, Garnick JJ, Lefkove MD. Linear tomography in conjunction with pantomography in the assessment of dental implant recipient sites. J Oral Implantol 1994;20:111-117.

9. Butterfield KJ, Dagenais M, Clokie C. Linear tomography's clinical accuracy and validity for presurgical dental implant analysis. Oral Surg Oral Med Oral Pathol Oral Radiol Endod 1997;84:203209.

10. Gher ME, Richardson AC. The accuracy of dental radiographic techniques used for evaluation of implant fixture placement. Int $\mathrm{J}$ Periodont Rest Dent 1995;15:268-283.

11. Mayfield-Donahoo TL, Stokely EM, Jeffcoat MK. Blur reduction of conventional film-based tomograms for pre-surgical evaluation of potential mandibular implant sites. J Periodontol 1997;68:362-368.

12. Todd AD, Gher ME, Quintero G, Richardson C. Interpretation of linear and computed tomograms in the assessment of implant recipient sites. J Periodontol 1993;64:1243-1249.

13. Potter BJ, Shrout MK, Russell CM, Sharawy M. Implant site assessment using panoramic cross-sectional tomographic imaging. Oral Surg Oral Med Oral Pathol Oral Radiol Endod 1997;84:436-442.

14. Oliveira RAP. Avaliação da precisão da tomografia linear e do sistema de digitalização indireta de imagens na mensuração da região anterior da mandíbula. [Master's thesis]. Porto Alegre: Faculty of Dentistry, PUCRS; 1999. 109p.

15. Kaeppler G. New radiographic programs for transverse conventional tomograms in the dentomaxillofacial region. Quintessence Int 1999;30:541-549.

16. Wyatt CCL, Pharoah MJ. Imaging techniques and image interpretation for dental implant treatment. Int $\mathrm{J}$ Prosthodont 1998; 11:442-452.

17. Bahlis A. Avaliação in vitro, em mandíbulas secas, da confiabilidade das medidas nas tomografias lineares. [Master's thesis]. 
Porto Alegre: Faculty of Dentistry, PUCRS; $1999.75 p$.

18. Catic A, Celebic A, Valentic-Peruzovic M, Catovic A, Vjekoslav J, Muretic I. Evaluation of the precision of dimensional measurements of the mandible on panoramic radiographs. Oral Surg Oral Med Oral Pathol Oral Radiol Endod 1998;86:242248.

19. Batenburg RHK, Stellingsma K, Raghoebar GM, Vissink A.
Bone height measurements on panoramic radiographs: the effect of shape and position of edentulous mandibles. Oral Surg Oral Med Oral Pathol Oral Radiol Endod 1997;84:430435.

20. Xie Q, Soikkonen K, Wolf J, Mattila K, Gong M, Ainamo A. Effect of head positioning in panoramic radiography on vertical measurements: an in vitro study. Dentomaxillofac Radiol 1996;25:61-66.

Accepted July 10, 2002 